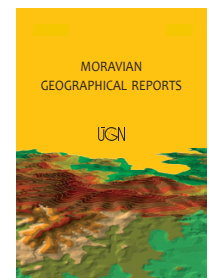

MORAVIAN GEOGRAPHICAL REPORTS

\title{
The importance of on-site evaluation for placing renewable energy in the landscape: A case study of the Búrfell wind farm (Iceland)
}

\author{
Bohumil FRANTÁL ${ }^{a *}$, Tadej BEVK ${ }^{b}$, Bregje VAN VEELEN ${ }^{c}$, \\ Mihaela HĂRMĂNESCU ${ }^{\mathrm{d}}$, Karl BENEDIKTSSON ${ }^{\mathrm{e}}$
}

\begin{abstract}
Using a case study of the Búrfell wind farm project, a large wind farm proposed in the Central Highlands of Iceland, the authors attempt to provide new insights into the factors shaping subjective landscape perceptions and attitudes to renewable energy developments, and into alternative methods that may be used for their assessment. The research was based on an on-site visit and actual experience of the place, investigated using a combination of mental mapping, the technique of the semantic differential and a questionnaire survey. The results show that participants visiting a landscape and using all sensory organs in combination with mental mapping, can reveal more important information than using only 'laboratory' methods with static photographs. The results suggest that the perception of landscape is highly subjective. Those perceiving the landscape as more open, homogenous, industrial, unfamiliar and resilient also consider it more compatible with wind turbines. The perception of the landscape's compatibility with wind turbines proved to be a dominant factor shaping attitudes towards the project. The acceptance of wind turbines is not, however, inconsistent with the perception of landscape as beautiful, wild and unique. Participants from more densely populated countries and countries with a developed wind energy industry were more tolerant of wind turbines in the Icelandic landscape.
\end{abstract}

Keywords: landscape perception; wind energy; on-site evaluation; mental mapping; semantic differential; Central Highlands of Iceland

Article history: Received 20 August 2017; Accepted 20 October 2017; Published 31 December 2017

\section{Introduction}

The natural resources of Iceland include an abundance of geothermal, hydropower and wind energy, of which only a part is currently being utilised. The cost of converting these resources to electricity is relatively low, making them attractive and highly marketable for industrial development (Gunnarsson and Gunnarsson, 2002; Ragnarsson et al., 2015).

Most of the high-temperature geothermal areas, powerful river systems and unusually high wind potential sites are located in the Central Highlands - a vast and unpopulated area that has become very popular among tourists due to its wild and barren landscape, with spectacular volcanoes and glaciers (Ólafsdóttir and Runnström, 2011). Plans for the further exploitation of the natural resources have been recently introduced, and include projects for large wind farms. These would be an entirely new element in the Icelandic landscape, potentially raising conflicts among different stakeholders, and creating new challenges for planners, policy makers and researchers (Sæpórsdóttir, 2011; 2012).

It has been suggested that the visual impact of wind turbines on the landscape is the most significant factor influencing local opposition (e.g. Wolsink, 2007; van Veelen and Haggett, 2016). Previous studies have attempted to quantify landscape impacts by assessing the landscape's physical characteristics, or by surveying visual preferences using static photographs, visualisations and similar

\footnotetext{
${ }^{a}$ Department of Environmental Geography, Institute of Geonics, CAS, Czech Republic (*corresponding author: B. Frantál, e-mail: frantal@geonika.cz)

${ }^{\mathrm{b}}$ Department of Landscape Architecture, Biotechnical Faculty, University of Ljubljana, Slovenia

${ }^{c}$ Department of Geography, Durham University, UK

d 'Ion Mincu' University of Architecture and Urbanism, Bucharest, Romania

${ }^{\mathrm{e}}$ Faculty of Life and Environmental Sciences, University of Iceland, Reykjavík, Iceland
} 
simulations (e.g. Sibille et al., 2009; Bětáková et al., 2015; Molnárová et al., 2012; Maehr et al., 2015). There is, however, also a growing body of evidence showing that the actual ex-post perception of landscapes with wind turbines might not be as negative as one might conclude from research employing surrogates (e.g. photographs) of landscape. A survey amongst tourists in the Czech Republic (Frantál and Kunc, 2011) shows only one quarter of visitors reporting a negative effect of wind turbines on the landscape. Similarly, de Sousa and Kastenholz (2015) did not find any particular influence of wind farms on rural tourism in Portugal. While tourists' perceptions of energy landscapes might differ from that of local residents, it might also suggest that the imagery of wind turbines itself is not the key negative impact, but more of a proxy through which dissatisfaction with the distribution of benefits and damages of a wind project is expressed (Baxter et al., 2013).

Furthermore, the studies also show a gap between 'laboratory' methods using surrogates of landscapes (photographs, visualisations) and those employing actual landscape experiences (places in situ). It has been shown that perceptions of the landscape are the result of the interaction of all senses (Jallouli and Moreau, 2009; Pedersen and Larsman, 2008), as well as a product of cognitive processes, where the physical setting is assessed through individuals cultural and personal backgrounds (Bidwell, 2013). The visual impact of wind turbines on acceptance is thus not linked just to the context of the physical landscape, but also to psychometric and socio-economic parameters which shape the way in which landscape is perceived and experienced (Kontogianni, 2014).

The landscape is therefore a subjective experience, and there is a certain difficulty in evaluating the appreciation of landscape, and in finding its main characteristics (Tress and Tress, 2001). Different methods are used for evaluating scenic value, the primary dichotomy being between expert-led and participatory methods (Cetkovský and Nováková, 2009). Another difference is that between methods using various rating scales or rankings of visual stimuli for the assessment of landscape perceptions and preferences, and methods using verbal descriptions or image expressions.

The aim of this paper is to provide new insights into the factors shaping landscape perceptions and attitudes towards renewable energy developments, and the research methods that may be used in this respect. Using the case study of the Búrfell wind farm project, the first large wind farm proposal in Iceland, the authors apply a combination of 'old-school' research methods and techniques which have been used only sparsely in the field of renewable energy planning. These methods include mental mapping and the semantic differential scales. We suggest that these methods (although more time-consuming to implement and evaluate) are not only an alternative to the more common use of photo-visualizations and rating scales, but provide an option for how to better capture and understand the subjective perceptions and preferences of people, and are thus helpful in the planning and decision-making processes for selecting the most appropriate locations for future renewable energy developments.

The paper has theoretical-cognitive, methodological and applied objectives. The cognitive objectives are identical to the more general problems described above and to the specific research questions formulated in section 4.2. The methodological objective is to enrich landscape research methodology in the context of renewable energy planning with techniques that have so far been sparsely used. The empirical findings can also offer useful insights for the future planning and design of wind farms beyond Iceland.

\section{Theoretical departures}

Nowadays, the energy transition towards renewable sources is conceived as a social issue with technical aspects, instead of the other way around (Pasqualetti, 2011). The social acceptance of renewables is high in general, but significant opposition often rises when implementing concrete projects. Such a behavioural gap was at first explained by (selfish) NIMBYism (Bell et al., 2005), but after extensive critique of such an oversimplification it is now often looked at through the lens of place attachment, landscape character and identity (Devine-Wright and Howes, 2010; van Veelen and Haggett, 2016). This perspective considers the physical character of the landscape and the emotional responses to this, to be a key component of place attachment. Thus, as 'place', the landscape is not a static, pre-given entity, but rather its meanings are contingent, and at times controversial, produced through practices of social and economic relations (Harvey, 1994; Massey, 2004).

Any adverse change of landscape will impinge on existing place identities and place attachments (Vorkinn and Riese, 2001; Devine-Wright and Howes, 2010). In this way, the change itself is the most controversial aspect and not necessarily the resulting landscapes. History provides many examples of at first purely technical landscapes being adopted, through time, by citizens and now seen as quality places and/or tourist attractions, not rarely put under protection (Edwards and Llurdés, 1996). Similarly, new renewable energy developments can be used for place branding and energy tourism development (Frantál and Urbánková, 2014), and they may contribute towards the construction of new and positive place identities (Walker, 2011).

It has been widely acknowledged that the physical parameters of renewable energy projects (such as the distance, number and height of wind turbines) alone are insufficient to explain opinions on a particular development. Rather, the place-based perspective advanced by DevineWright and others (van der Horst 2007; Devine-Wright and Howes, 2010; Devine-Wright, 2011; van Veelen and Haggett, 2016) has shown the importance of considering the socially constructed, symbolic dimensions of place, and how new developments are deemed to fit with these. The continued expansion of renewable energy into rural landscapes therefore requires a re-evaluation of the use and form of these landscapes, as well as the meanings and attachments embedded in them (Bridge et al., 2013).

It is also important to point out that perception is a selective process in which people have a tendency not to notice or more quickly forget stimuli that cause visual or emotional discomfort or contradict their prior beliefs (Bell, 2012). In this sense, Sæpórsdóttir (2011) found that in the minds of tourists, the Icelandic highlands represent wilderness and even though human influence there has been considerable (including several geothermal and hydro power plants, transmission lines and other infrastructures), most of the visitors still experience the area as 'unspoilt wilderness'. This indicates that people see what they want to see and they create and maintain in their minds an image of landscape that may emphasise or dismiss particular landscape features. This example of the 'social construction of the wilderness' in Iceland illustrates how wilderness or wild landscape is more a subjective idea than an empirical reality (cf. 
Sæbórsdóttir, 2011; Sæbórsdóttir and Saarinen, 2016). In a related study, however, Stefánsson et al. (2017) found that transmission lines and wind turbines have a negative effect on the perception of landscape, diminishing the feeling of wilderness, according to surveyed tourists.

The emergence of different place-related concepts and approaches to understand the perceived 'fit' of proposed or existing technologies in a particular place, has been accompanied by a proliferation of research methods. The most common way of conducting a visual impact assessment employs static photographs, often with a montage of proposed projects (Palmer et al., 2017). While photographs are generally accepted as a credible representation of landscape (Daniel and Meitner, 2001), there are still some unsettled fundamental questions, concerning both technical details (e.g. which focal length to use, how to set the landscape horizon, which format to use) and semantics (Svobodová et al., 2014; Palmer et al., 2017; Bevk et al., 2017). Ribe et al. (2018) report that the quality of simulation of landscape is an important factor in such studies and can have an effect on resulting preferences. They also report that research concerning the acceptability of wind energy development is lacking in rigorous experimental approaches.

Studies surveying visual preferences of landscape photographs with and without wind turbines mostly reveal a low acceptance of wind turbines in landscapes of high scenic quality and higher acceptance in unattractive landscapes (Lothian, 2008; Molnárová et al., 2012; Bětáková et al., 2015), and that wind turbines receive higher acceptance if their number is limited and they are located far away from observation points. They do not, however, reveal which specific landscape characteristics contribute to the perceived scenic value and the compatibility of wind turbines with landscape, or what contextual factors affect the perceptions and preferences.

Moreover, as photographs are simulations of real landscapes which only offer specific visual stimuli, the landscape experience evoked is inherently limited. Conversely, drawing from in situ experiences of landscape (i.e. actually being in the landscape) might produce richer information, as showed by some previous studies (Scott et al., 2008; Jallouli and Moreau, 2009). The study reported here uses a combination of personal visits to the site for a proposed wind farm and a subsequent survey of participants. The post-visit survey included techniques of mental mapping and using the semantic differential to discover what are the visual elements of the site and characteristics of landscape that are recalled and considered to be important in forming the participants' attitudes to a proposed wind energy development in the area.

\section{Geographical context of the study}

In recent decades the Icelandic economy has diversified from its fishing base to expand services (in particular international tourism) and energy-intensive industries (Gylfason and Wijkman, 2015). Due to its natural conditions, Iceland generates almost $100 \%$ of its electricity from renewable sources, about three-fourths from hydropower and one-fourth from geothermal energy (National Energy Authority, 2016). The consumption of electricity is extremely high when measured per head of population - well over $50 \mathrm{MWh} /$ capita in 2014, or more than twice that of Norway, the country that is next on the world list (Orkustofnun, 2017). The reason is that more than $75 \%$ of the relatively cheap electricity is sold to large industrial users, mainly three aluminium smelters and one ferrosilicon producer, plus a handful of smaller factories (Orkustofnun, 2016). This has raised concerns about the policy emphasis of successive governments on heavy industry, and its possible detrimental impact on Iceland's nature (Benediktsson, 2007; Karlsdóttir, 2013) and the fast-growing tourism sector (Sæbórsdóttir, 2010; Stefánsson et al., 2017).

International tourism in Iceland has grown rapidly in recent decades, and nature and 'wilderness' are considered the main attractions (Sæpórsdóttir and Saarinen, 2016). Specifically, the Central Highlands are often regarded as one of the last relatively pristine and wild environments left in Europe (Ólafsdóttir and Runnström, 2011). Traffic accessibility to the highlands has gradually increased since early 1970 s, mainly following the construction of hydro- and geothermal power plants with related infrastructure, which has subsequently transformed this wilderness into a recreational area (Sæbórsdóttir, 2010). Recently plans for further exploitation of the natural resources have been introduced, which have created new conflicts among different stakeholders and sectors of the national economy (Sæpórsdóttir, 2011; 2012). The highlands have thus become an arena of competition among different ways of seeing, interests, value judgments, myths and discourses regarding the potential use of the landscape, whether for renewable energy exploitation, ecotourism development or strict wilderness conservation.

In response to this changed arena, a project called the "Master Plan for Nature Protection and Energy Utilisation" has been established by the Icelandic government in order to assess and minimise negative environmental, social and economic impacts of proposed projects (Sæpórsdóttir and Ólafsson, 2010a). The task of the Master Plan is to compare the economic feasibility and environmental impacts of energy projects, which should aid in selecting the most feasible projects to develop. So far the Master Plan has been carried out in three sequential phases, each of which has contributed to the development of methodologies for assessing the energy sites, and for evaluating their qualities and impacts (Sæpórsdóttir and Ólafsson, 2010b). About 100 energy projects have already been evaluated and ranked, including the Búrfell wind farm.

One of the core subjects that experts are requested to evaluate at any proposed site in the context of the Master Plan, is the landscape. The methodologies used for evaluating the aesthetic values of landscape, and decisions on projects so far made, are subject to critical discussions, raising many questions. Waage and Jóhannesdóttir (2017) point out for example: "Who should define the aesthetic values of landscape?" or "When and how should these values be taken into consideration?"

\section{Material and methods}

\subsection{Case study area}

The proposal for the Búrfell wind farm was introduced by the National Power Company of Iceland ${ }^{1}$ in 2014 . It involves the construction of up to 67 wind turbines, each with a

1 The National Power Company of Iceland (Landsvirkjun) is the country's largest electricity producer and one of the largest producers of renewable energy in Europe. 
maximum height of 150 metres to the tip of the blade. Each turbine would have a capacity of 3.0-3.5 MW depending on the final turbine selection (Landsvirkjun, 2017). The construction area spans up to $40 \mathrm{~km}^{2}$ of lava and sand plain and is located to the east of the Tjórsá River, in an area where the energy company already operates two wind turbines for research purposes (see Figs. 1 and 2). The site has extraordinary wind potential with a capacity factor of over $38 \%$ on average, and the levelised cost of energy is estimated as about $0.088 \mathrm{USD} / \mathrm{kWh}$, which classifies Búrfell among the lowest-cost sites for wind energy in Europe (Ragnarsson et al., 2015).

The proposed project site is located in one of the largest energy production areas in Iceland. Currently, there are six operational hydropower plants located in the larger area, with their related structures such as tailrace canals, reservoirs, quarries, roads and transmission lines. The first power plant was commissioned in 1969 . The area can thus be considered as already considerably disturbed by human activities. The site is not defined as a protected area and is beyond the parameters of 'wilderness' as defined in the Nature Conservation Act (Ministry for the Environment and Natural Resources, 1999).

The site can be regarded as on the periphery of the highlands or - from another perspective - as a gateway and a stopping point on the way to the highlands, where 'true' wilderness can be experienced. The site is somewhat demarcated by a mountain range to the east and west, which would reduce the far-reaching visual impact of the wind farm. In an opinion survey (Ólafsdóttir et al., 2015), local residents were asked about the main characteristics of the surrounding landscape. The most common characteristics included sand, wilderness and lava; one fifth of respondents considered it a beautiful landscape, with a mountain view, a vast expanse, with lack of vegetation and much barren land. Approximately 10\% emphasised that the volcano Hekla is the main characteristic of the area (see Fig. 3).

Due to the size of the wind farm, the project was subject to an Environmental Impact Assessment (EIA), which was completed in 2016. Complete documentation is accessible at the company's website (Landsvirkjun, 2017). The Icelandic National Planning Agency (NPA) recently gave its negative opinion on the environmental impact assessment of the project, arguing it would have a significant impact on the landscape and wilderness in the area, as well as on tourism and recreation (Skipulagsstofnun, 2016). In the Regional Plan for the Central Highlands of Iceland, dating from 1999, the proposed construction area was defined as lying within a "structure belt", where major mountain roads and structures associated with electricity generation are allowed (Landsvirkjun, 2017). This plan has been superseded by the National Planning Strategy 2015-2026, however, where the preservation of the remaining wilderness in the highlands and their characteristic landscapes are emphasised (Skipulagsstofnun, 2016).

The proposal was one of those considered in the third phase of the Master Plan. Its current status within that planning process is 'on hold' (Rammaáætlun, 2017), which means that the project has not been definitely rejected, but that the company should find a more suitable location or scale down the project if it wants to proceed with it. Both solutions would require a new EIA process.

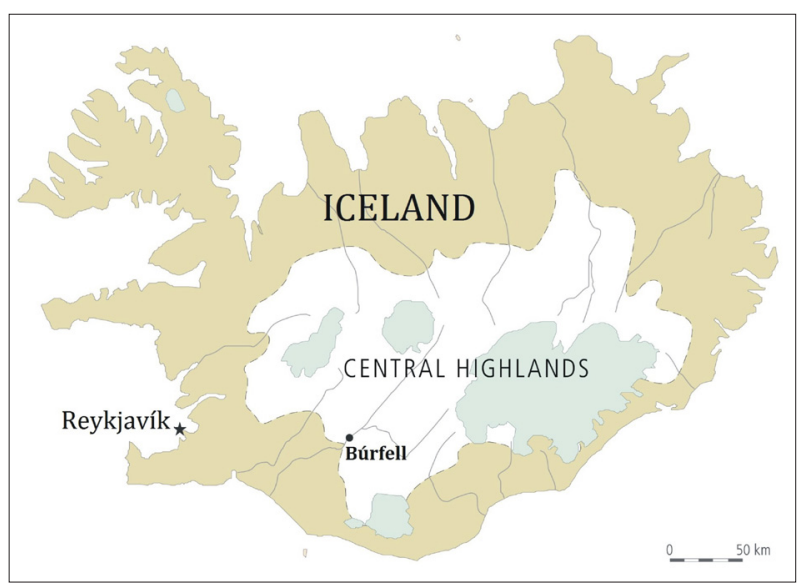

Fig. 1: Location of the Búrfell wind farm project in the Central Highlands of Iceland

Source: authors'elaboration

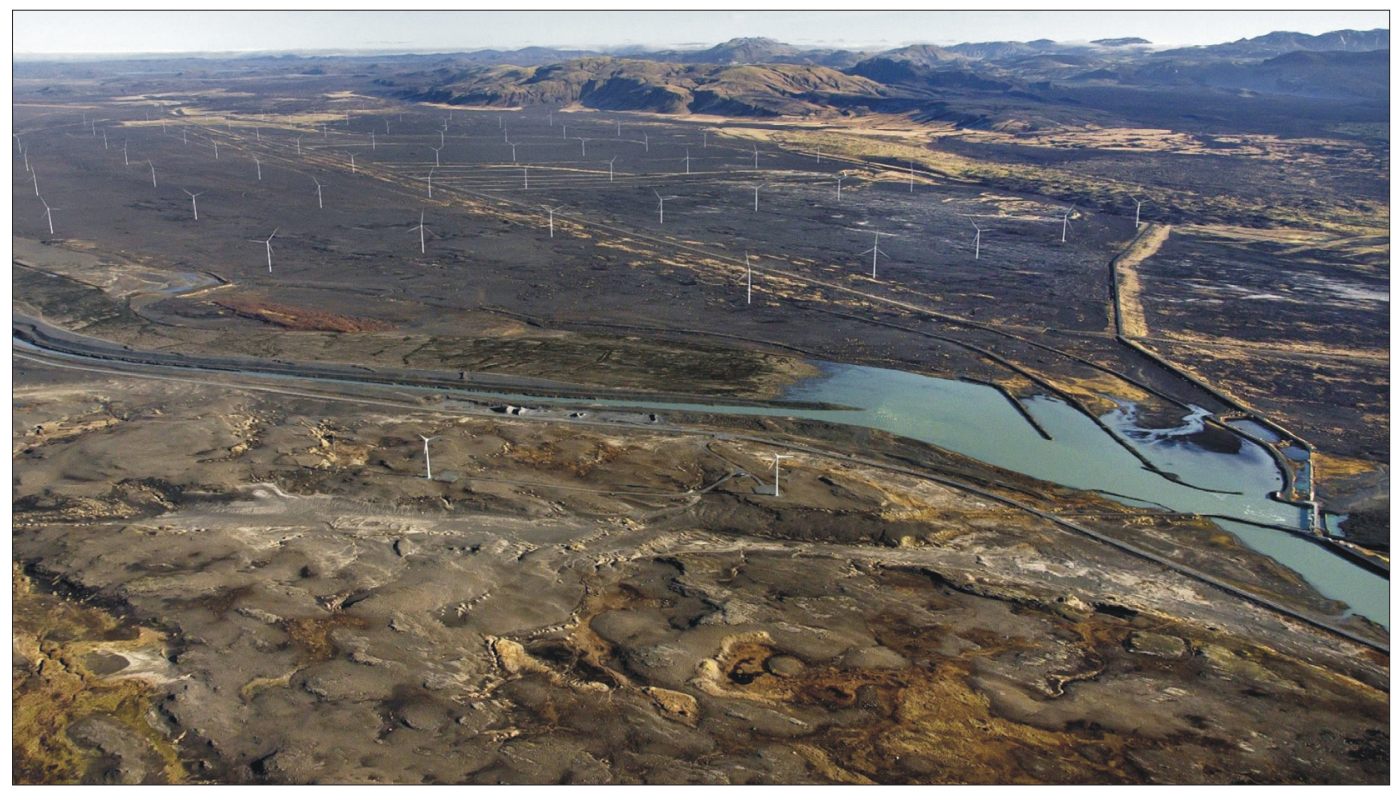

Fig. 2: Visualisation of the proposed wind farm. The two experimental wind turbines can be seen in the foreground, as well as the Bjarnalón Reservoir and the tailrace canal from the Sultartangi Hydropower Station Source: Landsvirkjun (2017) 


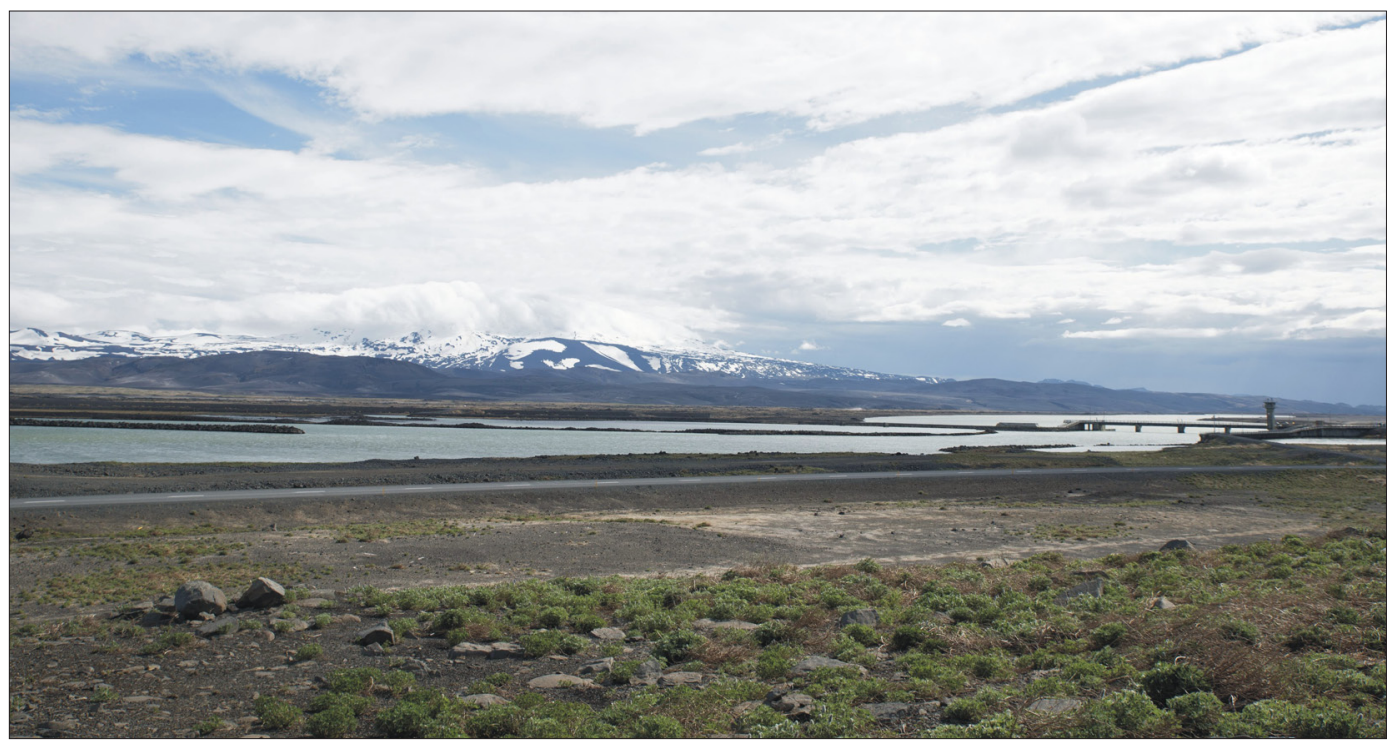

Fig. 3: The volcano Hekla, partly covered in clouds - one of the landscape dominants in the Búrfell area Photo: T. Bevk

\subsection{Research questions}

The specific research questions that have driven this empirical study were defined as follows:

1. How is the Icelandic landscape perceived, in general? And, specifically, how is the Búrfell landscape perceived? Are there significant differences between these perceptions?

2. What visual elements of the Búrfell landscape are considered to be important? How are those visual elements arranged spatially?

3. How compatible with the Búrfell landscape are wind turbines perceived to be?

4. How strongly do landscape perceptions relate to the attitude of accepting or rejecting the wind farm project?

5. What other factors influence public opinions about the project?

The results presented in section 5 have been structured into sub-sections reflecting these research questions.

\subsection{Research methods and procedures}

This paper is an output of research carried out during the Training School: Questions of Power and Participation: Renewable Energy and Landscape in Policy and Planning, held in May 2017 in Iceland, within the scope of the COST Action RELY (see 'Acknowledgements' for more information). Altogether 30 people from 17 countries participated in the survey. Even though the group consisted of people with varied professional backgrounds (geographers, sociologists, urban planners, landscape architects and engineers), the professional interests of all participants are in some way connected with the issues of renewable energy development and its impacts on the landscape. In this sense, they cannot be considered as 'normal' tourists, but rather as 'expert tourists' within the so-called special interest tourism (Brotherton and Himmetoğlu, 1997; Frantál and Urbánková, 2017). The group was evenly represented by both genders (fifteen males and fifteen females) and different age groups (one third of people under the age of 30, one third between 30 and 40 years, and one third over 40 years old). About two thirds of the participants were first-time visitors to Iceland. The research had an exploratory character and included several phases: a field trip with observations and note-taking; analysis of notes; mental mapping; the construction of relevant semantic differential items; a questionnaire survey; and detailed data analysis and interpretation.

First, the participants were asked to observe the landscape during a one-day field trip that included several locations in Southern Iceland and the Highlands. They were encouraged to write down their feelings and impressions (preferably using adjectives) associated with the Icelandic landscape in general, as well as specific impressions related to the Búrfell site. The visit to the Búrfell site (see Fig. 4) lasted approximately one hour, during which the participants studied an information board presenting basic data about the project and photo visualisation of the wind farm, as well as observing the landscape and the two existing turbines first hand. Also the planned project was discussed with some local experts. The day after the visit, verbal characteristics of landscapes in the form of adjectives as recorded by participants were summarised, sorted and categorised into groups representing different attitude factors, such as evaluation, potency, activity, typicality and complexity (cf. Echelberger, 1979). Afterwards, selected participants (members of a specific working group at the training school, and then the authors of this paper) drew mental maps of the Búrfell site as a means of scoping - to find the most memorable characteristics and the level of agreement between them.

Mental mapping is a valuable tool for understanding how humans perceive and reflect their environment. A mental map using the well-known sketch map technique, reveals an individual's spatial cognition of a landscape that is the reflection of a mental construction of spatial arrangements in memory sketched on paper (Uusitalo, 2010). The conceptual structure of a mental map reflects the manner in which space is represented and apprehended, revealing spatial preferences and attractiveness of specific elements of the landscape. In some cases, mental mapping has been used to engage local residents in the planning process of wind farms, as a tool to express personal preferences about the location of wind farms based on local knowledge (Nováková and Frantál, 2009). Additionally, mental maps include non-spatial components reflecting attributive values, meanings, attitudes and understandings about places which influence individual behaviours 
(Uusitalo, 2010). Several typologies were made for studying the content and the structural quality of the sketch maps. The structure of maps, their components, style, content, inclusion or exclusion of elements, accuracy (complexity), interrelation between the types of visual elements and alike, can be analysed in different ways (Appleyard, 1970; Whyte, 1977). Lynch (1960), for example, in his research on the understanding of urban space, defined five key elements in mental maps - nodes, paths, edges, districts and landmarks. While this approach focuses on the content of the maps, others also analyse the composition, view angle and centrality of drawn objects (Ueda et al., 2012).

In our case study, the mental maps were used to determine the scope of perceptions. Based on the on-site visit to the studied landscape, each of the authors drew their own mental map (see Fig. 4). The subsequent analysis of maps exposed how similar the perceptions of this landscape were. The analysis was based on what was drawn, where and how. What is drawn - the content - is more or less selfexplanatory: objects appearing repeatedly in the drawings are considered memorable characteristics of the landscape. Where something is drawn - the position of an object on the paper - indicates its importance. Objects drawn centrally or in the foreground of the paper are considered more important than those drawn at the edges or peripherally, but this might also be the consequence of a chosen viewpoint. This is why we also assessed the relative size of drawn objects as a proxy of importance, as objects found more important tend to be drawn larger. While, by themselves, the findings of the mental maps can be used immediately to begin drafting the character of a landscape, we mainly used them to facilitate the construction of a questionnaire in the next phase. Mental mapping and brainstorming of adjectives which describe the landscape, supported by a literature review (Echelberger, 1979; Kaplan, 1985; Kim and Kang, 2009; Natori and Chenoweth, 2008; Zube and Pitt, 1981), facilitated the construction of the semantic differential items for measuring the perceptions of the Búrfell site landscape.

Several authors have argued that people can explain their preferences better by using words than by rating or ranking visual stimuli (Kaymaz, 2012). In the semantic differential technique developed by Osgood et al. (1957), respondents use a series of bipolar adjective pairs to judge a 'concept', which - in our case - can be a landscape (as a general concept) or particular landscape scenery (the Búrfell wind farm site). Respondents decide whether a concept is associated more with adjectives such as beautiful or ugly, common or unique, and to what degree. When data are then subject to factor analysis, one factor that emerges can be considered an index of attitudes or an evaluation of the concept. This index can be labelled as the evaluative factor or attitude score (Echelberger, 1979). It can then be tested whether there is a relation between the assessment of specific landscape characteristics and the attitude of respondents to a particular use of land, e.g. to exploit or to preserve it.

Besides a semantic differential list including 20 pairs of adjectives, the constructed questionnaire included two questions asking participants to assess the compatibility of the proposed wind farm with the landscape, and to state their position in terms of approval or non-approval of the project. Another (open-ended) question asked people to explain in greater detail their attitude to the project by listing important arguments for or against it. We also considered the personal characteristics of participants, including gender, age, profession and country of origin. The data from the questionnaires were digitised and analysed using the SPSS software (version 21), providing descriptive statistics, analysis of variance, principal components analysis and correlation analysis.

Finally, it is worth mentioning that we are well aware of some methodological limitations of this study, particularly concerning the overall levels of perceived compatibility and approval of the projects, and the verification of the influence of respondents' socio-demographic characteristics on perceptions and attitudes. This limitation is caused by the small sample of respondents, which is also relatively homogenous with respect to professional background. This study was, however, not aimed primarily at the estimation of population parameters but rather at exploring specific relative factors and the relationships among them, and testing specific research methods and techniques, albeit for a restricted sample, as noted.

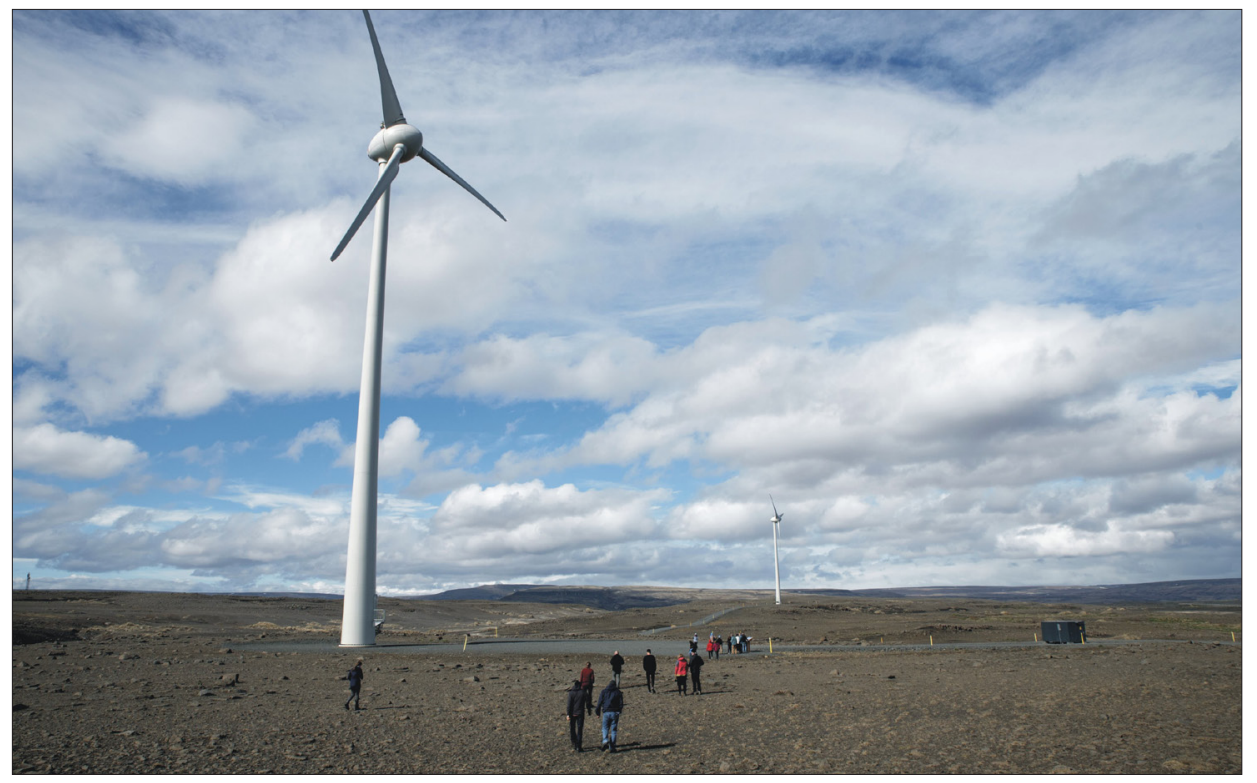

Fig. 4: Participants of the survey with the two operational wind turbines

Photo: T. Bevk 


\section{Results}

\subsection{Associations connected to landscapes of Iceland and Búrfell}

The most commonly recorded words associated with the Icelandic landscape in general, were diverse and contrasting, open, wild, beautiful, vast and breath-taking. Other frequent adjectives related to the 'potency' of the landscape, such as powerful, energetic, and dynamic. Some adjectives related to specific natural elements which constitute the Icelandic landscape (volcanic, rocky and deserted) were also mentioned by several people. While open, breath-taking and powerful were also oft-mentioned for the Búrfell site, there were also some other key site-specific adjectives, including disturbed, industrial, bleak, desolate and windy. This appears to indicate a difference in perception of the Búrfell site compared to Icelandic scenery in general (see Tab. 1). Differences in perceptions and the experience of a particular place (Búrfell) are also evidenced by the completely contradictory associations often mentioned: while for several people the Búrfell landscape was noisy, dangerous and scary, it impressed others as being rather quiet, relaxing and meditative.

\subsection{Interpreting mental maps of the Búrfell landscape}

The perception of the Búrfell wind farm site as anthropogenically changed and disturbed (as interpreted from the frequency of recorded adjectives) is also reflected in the mental maps (see Fig. 5). The most common characteristics of the site as drawn were the human interventions (wind turbines, dam, road), but there were also two distinct natural features (Hekla volcano, surrounding hills) that were drawn by all participants. The flat plain on the left of the drawing behind the existing wind turbines was mostly left out with no drawn features. This empty space of the drawing might suggest this area is lacking features that would characterise it, echoing some of the adjectives used in associations such as empty and desolate. The idea of building wind turbines in this "blank" area appeared several times in response to an open question (see Tab. 5).

\begin{tabular}{lll}
\hline Icelandic landscape (in general) & Búrfell landscape (specific) & Contrasts (general vs. site-specific) \\
\hline diverse (contrastful) & open & impulsive-passive \\
open & disturbed & contrasted-homogeneous \\
wild & bleak (desolate) & quiet-noisy \\
beautiful & industrial & beautiful-ugly \\
vast & windy & unspoiled-industrial \\
breathtaking (mesmerising) & vulnerable-exploitable \\
powerful (energetic) & breath-taking & old-innovative \\
barren (uncultivated) & powerful (energetic) & \\
lunar (alien, martian) & noisy & \\
\hline
\end{tabular}

Tab. 1: The most common perceptions and contrasts of landscapes of Iceland and Búrfell Source: authors'survey

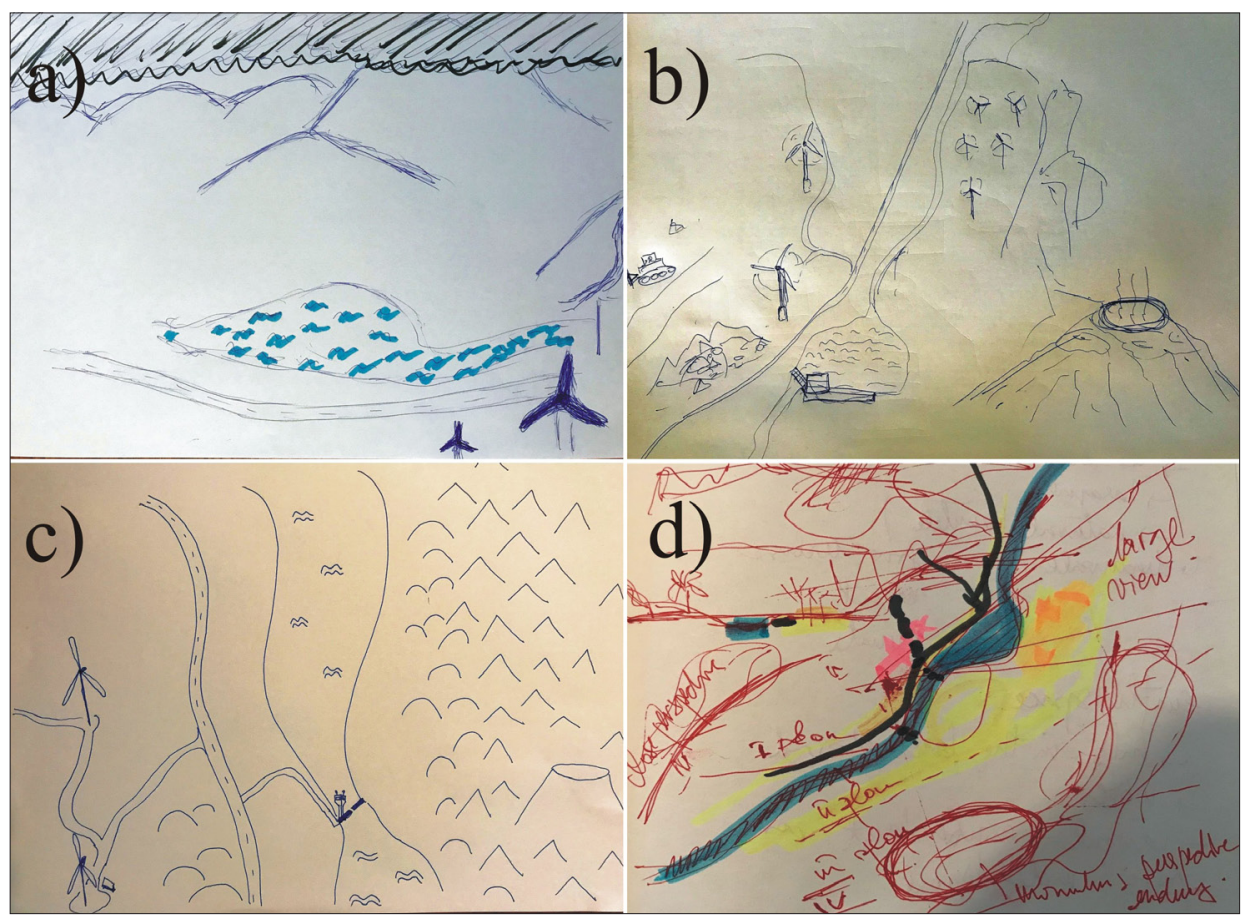

Fig. 5. Mental maps of the Búrfell site

Source: authors' elaboration 
The water reservoir appears centrally on all of the drawings suggesting this might be the key characteristic of this site. As the wind turbines are drawn quite large for the scale of the drawings, it is possible to say that observers were focusing on them to a large extent. These two findings might point towards a landscape character defined by the energy infrastructure, but the fact that the drawings were made by experts interested in renewable energy might also explain why such an infrastructure is emphasised. All of the drawings offer a bird's-eye view of the landscape, suggesting a somewhat detached, objectivistic approach to landscape assessment (Ueda et al, 2012).

\subsection{Perception of landscape compatibility and project approval}

Two closed questions were included in the survey, asking participants to assess (on a 5-point Likert scale) the compatibility of the proposed wind farm with the Búrfell landscape, and their position in terms of approval or non-approval of the project. One half of the respondents considered wind turbines incompatible with the landscape, while about one-third perceived them as compatible. Also almost half of the respondents would rather reject the project, while only about one third would approve it (see Fig. 6). A strong correlation (Spearman's rho $=0.69$ ) was found between the perceived compatibility of the wind farm proposal with the landscape and personal attitude to the project.

In fact, there were only two respondents who would rather disapprove of the project although they considered wind turbines very or rather compatible with the landscape. The reason for such a decision is that they considered the project redundant in the context of Iceland's already large energy production. On the other hand, there were two people who would approve the project even though they considered wind turbines incompatible with the landscape. The reason for such a decision was their support for renewable energy in general and an opinion that although the selected site "is not the best, it is even not the worst". A deeper discussion of the arguments for and against the project approval is presented in section 5.5.

\subsection{Semantic differential analysis}

The analysis of data from the semantic differential items revealed significant differences in the perception of the Búrfell landscape. The biggest consensus among respondents was that the local landscape is exposed, open, unfriendly, windy and kind of unique. Some people, however, perceived the landscape as natural, diverse, colourful and familiar, while others perceived it rather as man-made, homogenous, monochromatic and alien (see Tab. 2).

Figure 7 visually shows the differences in perceptions of the Búrfell landscape between those who consider the project to be compatible and those who consider it as incompatible with the landscape. People who perceive the landscape as more open, homogenous, industrial, alien and resilient, also evaluate the wind farm as compatible with the landscape. On the other hand, those who perceive the landscape as less open, more diverse, pastoral, familiar and vulnerable consider the project as incompatible with the landscape.

Somewhat paradoxically, people who perceive the landscape as slightly more beautiful, wild and unique consider the project more likely as compatible with the landscape. This difference, however, proved not to be statistically significant. The perceptions of beauty and

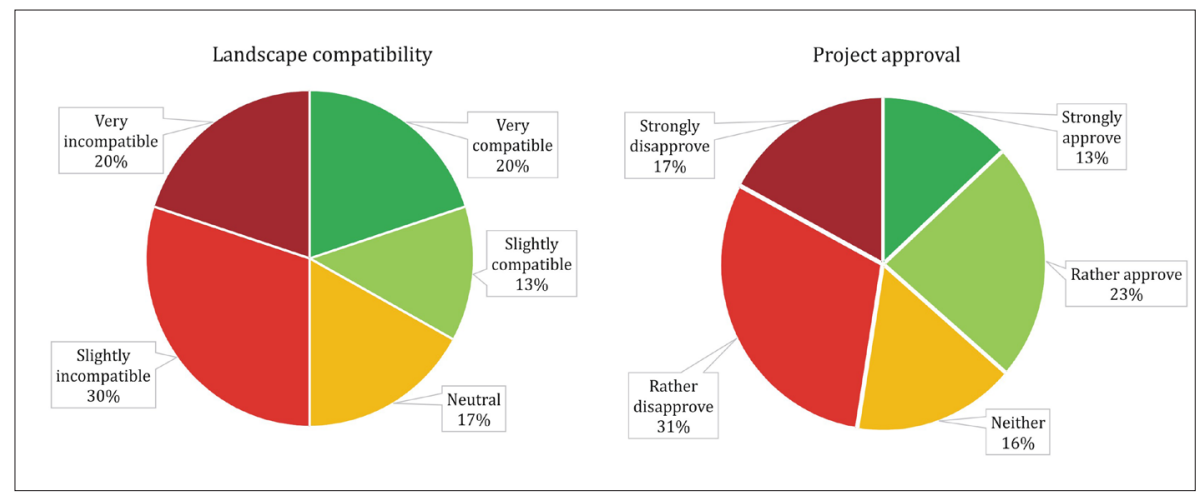

Fig. 6: Perceptions of compatibility of wind farm with the landscape and attitudes to project approval Source: authors' survey

\begin{tabular}{lll}
\hline $\begin{array}{l}\text { Adjectives } \\
\text { with the lowest rate of variance } \\
(\text { Var < 1.0) }\end{array}$ & $\begin{array}{l}\text { Adjectives } \\
\text { with the highest rate of variance } \\
(\text { Var }>1.4)^{\mathbf{1}}\end{array}$ & $\begin{array}{l}\text { Adjectives significantly correlated } \\
\text { with the perception of compatibility } \\
\text { (value of correlation })^{\mathbf{2}}\end{array}$ \\
\hline $\begin{array}{l}\text { Exposed } \\
\text { Open }\end{array}$ & $\begin{array}{l}\text { Young / Old } \\
\text { Man-made / Natural }\end{array}$ & $\begin{array}{l}\text { Open }\left(0.37^{*}\right) \\
\text { Resilient }\left(0.29^{*}\right)\end{array}$ \\
Unfriendly & Homogenous / Diverse & Homogenous $\left(0.26^{*}\right)$ \\
Windy & Monochromatic/Colourful & Industrial $\left(0.24^{*}\right)$ \\
Unique & Alien / Familiar & Alien $\left(0.21^{*}\right)$ \\
\hline
\end{tabular}

Tab. 2: Adjectives related to Búrfell wind farm landscape (Notes: ${ }^{1}$ Adjectives with slightly higher degree of preference are underlined; ${ }^{2}$ Values of correlation (Somers' d) for the perception of compatibility as dependent variable are significant at * 0.05 level). Source: authors' survey 


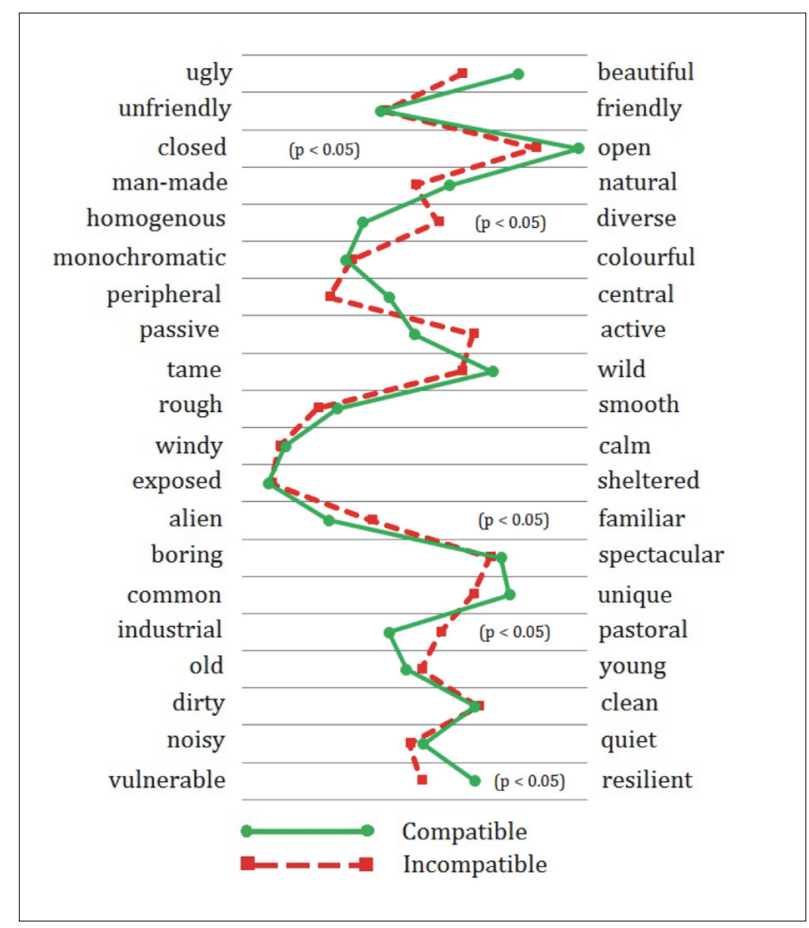

Fig. 7. Differences in perception of the Búrfell wind farm landscape between those who consider the project to be compatible and those considering the project incompatible with the site. Note: Levels of significance (p) for adjectives that significantly correlate with the perception of compatibility.

Source: authors' survey wilderness (as the most typical characteristics of Icelandic landscape in general, as emphasised in the literature) proved to be strongly correlated $(\mathrm{r}=0.56)$. Besides that, both the perception of beauty and wilderness significantly correlate with the characteristics of natural, spectacular, pastoral and unique.

In order to explore the structure of relations among specific characteristics of landscape and to find out if they can be divided into groups representing more generic 'factors', we applied principal component analysis (PCA). Five items (peripheral/central, passive/active, rough/smooth, familiar/ alien, vulnerable/resilient), which correlated weakly $(<0.3)$ with others, were excluded from the PCA. The results of analysis are presented in Table 3 . The presented grouping of items was generated using the Oblimin rotation solution with the measures of the Kaiser-Meyer-Olkin test of sampling adequacy $(\mathrm{KMO}=0.71)$ and Barlett's test of sphericity $(p<0.001)$ confirming appropriateness of the selected variables for the factor analysis. The total variance explained by four extracted components is nearly $70 \%$.

The first component, which can be considered an evaluative factor explains $35 \%$ of the total variance. The second component, including characteristics expressing the impact of human activities on the landscape, explains 15\% of the total variance. The third component (called potency) explains nearly $11 \%$ of total variance and the fourth component (which we called exposure) explains about 7\% of total variance. Only the fourth component (including the adjectives of open, noisy and common), however, proved to be significantly correlated with the perceptions of landscape compatibility and project approval.

\begin{tabular}{|c|c|c|c|c|}
\hline \multirow{2}{*}{ Adjectives } & \multicolumn{4}{|c|}{ Component } \\
\hline & Evaluation & Human impact & Potency & Exposure \\
\hline homogenous / diverse & 0.83 & & & \\
\hline monochromatic / colourful & 0.82 & & & \\
\hline boring / spectacular & 0.77 & & & \\
\hline ugly / beautiful & 0.49 & & & 0.36 \\
\hline man-made / natural & & -0.91 & & \\
\hline old / young & 0.38 & 0.73 & & \\
\hline tame / wild & & -0.67 & & \\
\hline industrial / pastoral & & -0.61 & & \\
\hline windy / calm & & & -0.83 & \\
\hline exposed / sheltered & & & -0.71 & \\
\hline unfriendly / friendly & 0.35 & & -0.68 & \\
\hline dirty / clean & & & -0.59 & \\
\hline closed / open & & & 0.35 & 0.73 \\
\hline quiet / noisy & & & & 0.63 \\
\hline common / unique & 0.40 & & & -0.45 \\
\hline$\%$ of Variance explained & 35.1 & 15.2 & 10.9 & 7.4 \\
\hline correlation with landscape compatibility & n.s. & n.s. & n.s. & $0.47^{*}$ \\
\hline correlation with project approval & n.s. & n.s. & n.s. & $0.41^{*}$ \\
\hline
\end{tabular}

Tab. 3: The extracted components of landscape characteristics

Notes: Principal Component Analysis, rotation method Oblimin with Kaiser Normalization. Factor loadings lower than 0.3 were excluded. Correlation that is significant at the 0.05 level is indicated with a star (*)

Source: authors' survey and calculations 


\subsection{Factors affecting landscape perceptions and attitudes}

Relationships between perceptions and attitudes and socio-demographic characteristics were also tested. Our results suggest that males were more likely to perceive the proposed wind farm as compatible with the landscape than females (47\% versus $20 \%$ ). The reported difference in the level of approval between genders (the project would be approved by $40 \%$ of males but only by $33 \%$ of females) proved not to be statistically significant, however (see Tab. 4). Older people (over 30 and especially over 40 years old) are slightly more tolerant to the project than younger persons (up to 30 years). But these differences are also not statistically significant. Any links between personal attitudes and professional background of people were also not found. There is however a significant correlation (even in such a small sample of respondents) between the subjective perception of landscape compatibility and approval of the project and a respondent's country of origin. People from more denselypopulated countries and countries with an already developed wind energy industry (e.g. Netherlands, Germany, UK) are much more tolerant of the project.

Nevertheless, the subjective perception of landscape and its compatibility with wind turbines is the dominant factor shaping personal attitude to project approval. This is finally supported also by the analysis of information from the open-ended question asking people to explain their stated attitude to the project by summarising key pros and cons of the project. The key arguments of advocates and opponents of the project are summarised according to their relative frequency in Table 5 . The aspects of potential visual impact of the wind farm on the local landscape and the need for the production of more energy emerged as the main points of contention.

\section{Discussion and conclusions}

In general, our research has confirmed that wind turbines are a controversial element which some people perceive primarily negatively, while others quite positively, whether the landscape is in the Icelandic highlands, part of the rural countryside in Central Europe (Frantál and Kunc, 2011) or on the North Sea coast (Gee, 2010). Landscape perception and experience is a highly subjective and relative phenomenon, influenced by the perceiver's motivations, values and cultural background and their situation in life, as well as the time spent in a place and level of place attachment (i.e. differences in the perceptions by tourists and locals).

Our survey found that half the respondents considered wind turbines incompatible with the landscape, while about one third perceived them compatible. Also almost half of the people would rather reject the project, while more than a third would approve it. Similar contrasting perceptions and attitudes were reported from a questionnaire survey using photo-visualisations of the proposed wind farm, conducted in 2014 and with a sample of some 1,351 tourists in Iceland (Björnsson et al., 2015). While approximately $40 \%$ of tourists had generally positive attitudes to wind turbines in the Icelandic nature, $33 \%$ had a negative attitude to them, and nearly one fifth reported tending to avoid travelling in areas with wind turbines. Concerning specifically the Búrfell wind farm, about $35 \%$ had a positive attitude to

\begin{tabular}{lcc}
\hline \multirow{2}{*}{ Predictors } & \multicolumn{2}{c}{ Value of correlation with } \\
\cline { 2 - 3 } & Perceived compatibility & Project approval \\
\hline Gender & $0.36^{*}$ & n.s. \\
Age & n.s. & n.s. \\
Profession & n.s. & n.s. \\
Country of origin: Population density & $0.38^{*}$ & $0.32^{*}$ \\
Country of origin: Wind energy capacity per $\mathrm{km}^{2}$ & $0.40^{*}$ & $0.38^{*}$ \\
\hline
\end{tabular}

Tab. 4: Factors affecting the perception of landscape compatibility and attitudes to the project. Note: Values of correlation (Somers' $d$ for ordinal variables and Pearson's $r$ for numeric variables) are significant at the *0.05 level Source: authors' survey and calculations

\begin{tabular}{ll}
\hline For approval & For rejection \\
\hline $\begin{array}{l}\text { - no special scenic landscape (similar vast plains with volcanic } \\
\text { rocks elsewhere), there will be plenty of opportunities to view }\end{array}$ & $\begin{array}{l}\text { - the views to the mountains in the east and south will be spoiled } \\
\text { (particularly the view on Hekla volcano), negative impact on } \\
\text { tourist experiences }\end{array}$ \\
$\begin{array}{ll}\text { Hekla volcano from other places } & \text { - landscape is already changed but still the large wind turbines } \\
\text { - landscape already disturbed by human activities (energy } \\
\text { production), existing infrastructure (roads, transmission lines) }\end{array}$ & $\begin{array}{l}\text { will disturb and change the existing landscape dramatically } \\
\text { - extraordinary wind potential, energy economically feasible without }\end{array}$ \\
$\begin{array}{l}\text { subsidies (we need to use cheap wind energy where available) } \\
\text { produce more energy just because we can) }\end{array}$ \\
$\begin{array}{l}\text { - empty, deserted, uninhabited land (far from settlements) with } \\
\text { low biodiversity }\end{array}$ \\
$\begin{array}{l}\text { - too bing and concentrated project (better more single wind } \\
\text { turbines in lowland farming areas) }\end{array}$ \\
$\begin{array}{l}\text { beautiful themselves) } \\
\text { - better to construct the wind farm on the other side of the road }\end{array}$
\end{tabular}


the project while about $40 \%$ had a negative attitude (25\% were neutral) (Björnsson et al., 2015). Conversely, the study of Stefánsson et al. (2017) reveals that wind turbines are considered inappropriate for some more naturally preserved areas in the eyes of tourists.

Our survey data showed a strong correlation between the perceived project's compatibility with the landscape and attitudes towards the project (section 5.3). This could indicate that a project's perceived 'fit' in the landscape plays a key role in determining attitudes towards it. This may be explained by the types of participants in this study, but it also indirectly supports previous research which has found that people who have spent less time in a place may be more likely to evaluate proposed developments based on their impact on the physical landscape (as well as individuals' emotional attachments to this landscape) than on the proposed development's impact on the local populations (Hidalgo and Hernandez, 2001).

Both the mental mapping exercise and the survey data show that the presence of human-made structures in a landscape are important in shaping public perceptions of the landscape and attitudes to its future use. Individual perceptions of the Búrfell site are, however, rather contradictory: bleak, industrial and scary, but also breathtaking (and for some, even meditative). Nevertheless, our results show that the main values of the Highlands landscape as pointed out by the National Planning Agency in their decision about the project (i.e. wilderness, unspoiled nature, beauty), are not the ones generally perceived by our survey participants at the site. The bone of contention seems to be rather the question of how much the landscape is already disturbed and how the proposed project may further damage the already-disturbed landscape.

Respondents who perceived the landscape as more open, homogenous, alien, industrial and resilient, also evaluate the wind farm as compatible with the landscape. Of further interest is that those who perceive this particular landscape as slightly more beautiful, wild and unique, consider the project more likely to be compatible with the landscape. This finding can indicate that the use of wind energy is not in strict contrast with the perceived beauty, wilderness and uniqueness of the landscape. This perception can be well illustrated by one respondent's statement:

"I do perceive such wide and wild landscapes (Búrfell), dominated by morphology, as absolute and atemporal landscapes, where the dimensions and the horizons seem to visualise the perpetual movement of the Universe and suggest the renewability of the natural phenomena such as wind (...) In my vision this complex of factors perfectly suits the proposed wind farm".

Similarly, Vorel (2009) suggested that wind turbines can be perceived as compatible with some kinds of landscapes (e.g. segments of visually open cultural landscape, working agricultural landscapes, or post-industrial landscapes) and they can even contribute positive aesthetic values, like a 'hitech' product. Such statements call for a search of landscape settings that might have some sort of 'natural' fit with wind turbines, and may therefore not only be less disturbed by them compared to other types of landscape but may even benefit from such installations. In this regard, we might also ask if a new type of landscape is emerging with the spread of renewables - a landscape of renewable energy?

The physical landscape and emotional responses to it are not, however, the only factors that influence attitudes to renewable energy developments. Those advocating a place attachment perspective have emphasised that the social dimensions of place, i.e. current and historical social or cultural attachment to an area, also play a role in shaping opinions of new developments (Raymond et al., 2010; Lin and Lockwood, 2014). As this particular landscape at Búrfell is generally not seen as incredibly beautiful, where nothing should be built, but neither as a completely worthless place, a key piece of information seems to be missing - just how important is this wind farm project for Iceland's energy provision and/or for the local area? As other research has shown (Stefánsson et al., 2017; Llewellyn et al., 2017; van Veelen and Haggett, 2016), local perceptions of renewable energy projects are at least in part based on the ways in which such developments are expected to benefit the local area and for what purposes the produced energy will be used. Without this knowledge it is difficult if not impossible to establish a value system within which the benefits could be compared to damages done to the landscape.

Finally, our survey also found that people from more densely populated countries and countries with an alreadydeveloped wind energy industry are much more tolerant to wind turbines in the landscape. This seems to be in contrast to the study by Bishop and Miller (2007), who found that those who lived in areas where turbines had been approved were more negative than those whose localities were still untouched by the wind energy industry, but in line with the findings of Stefánsson et al. (2017) that tourists from Germany, Switzerland and the UK are more tolerant of energy infrastructures than those from Nordic countries.

From the methodological perspective, our research shows that visits to the actual landscape, with the involvement of all sensory organs, can reveal more information than using 'laboratory' methods and static photographs (photovisualisations). Ribe et al. (2018) have argued that field studies might not be able to provide useful findings about wind energy project perceptions, calling for more rigid and controlled laboratory experiments. While this may be true when searching for universally applicable principles, no development project is carried out in vitro, and each affects a certain landscape and certain people. We would therefore like to add that on-site studies, such as the one reported here, are and should be an indispensable factor in the toolbox for wind power development, especially when it comes to evaluating specific locations.

The experience of 'blowing wind energy' at the site, as well as the perception of the landscape as wide-open, noisy and exposed, were considered by many people to be important aspects of the landscape when they made up their minds about the project. It is necessary to admit that perceptions of actual landscapes can be significantly influenced, for example, by varying weather conditions, the context of the study and researchers' biases, to name a few factors. In this sense, it is desirable to compare the perceptions of one-day visitors with those of locals who have long-term experiences with the landscape. The use of mental mapping helped to reveal which parts of the landscape are recalled and considered important and valuable, and which are perceived as marginal or empty. It brings up the idea of using mental maps as a tool in planning: perhaps the method could be used to identify 'empty spaces' in the landscape and direct developments there.

The combination of qualitative and quantitative research methods described in this article has proved fruitful in terms of both constructing the survey instrument 
and interpreting the results. We therefore urge and suggest further examination of how such qualitative and quantitative methods can be used jointly to yield informative findings on planning renewable energy projects in the landscape.

\section{Acknowledgement}

This paper is an output from the COST Action project: "Renewable Energy and Landscape Quality (RELY)" (TU1401); with contributions from the national project: "Exploring social-spatial diffusion of renewable energy projects in the Czech Republic: Lessons for adaptive governance of energy transition" (Czech Science Foundation, No. 16-04483S); and the UK ESRC doctoral training program. We thank two anonymous reviewers for their helpful comments on a draft manuscript.

\section{References:}

APPLEYARD, D. (1970): Styles and methods of structuring a city. Environment and Behaviour, 2: 100-117.

BAXTER, J., MORZARIA, R., HIRSCH, R. (2013): A casecontrol study of support/opposition to wind turbines: Perceptions of health risk, economic benefits, and community conflict. Energy Policy, 61: 931-943.

BELL, S. (2012). Landscape: pattern, perception and process. New York, Routledge.

BELL, D., GRAY, T., HAGGETT, C. (2005): The 'social gap' in wind farm siting decisions: explanations and policy responses. Environmental politics, 14(4): 460-477.

BENEDIKTSSON, K. (2007): 'Scenophobia' and the aesthetic politics of landscape. Geografiska Annaler B, 89(3): 203-217.

BĚŤÁKOVÁ, V., VOJAR, J., SKLENIČKA, P. (2015): Wind turbines location: How many and how far? Applied Energy, 151: 23-31.

BEVK, T., MESTRE MARTINEZ, N., BRERETON, P., LALOŠEVIČ, M., PERIČ, M. (2017): Iterative Digital Photo-based Assessment for Rural Landscape Perception: A Small Experiment from County Wicklow, Ireland. Journal of Digital Landscape Architecture, 2017(2): 18-27.

BIDWELL, D. (2013): The role of values in public beliefs and attitudes towards commercial wind energy. Energy Policy, 58: 189-199.

BISHOP, I. D., MILLER, D. R. (2007): Visual assessment of off-shore wind turbines: the influence of distance, contrast, movement and social variables. Renewable Energy, 32(5): 814-831.

BJÖRNSSON, G., SÆPÓRSDÓTTIR, A. D., ÓLAFSDÓTTIR, R. (2015): The Impact of Wind Farms on Tourist Experience in Iceland's Highlands. Poster presented at the $21^{\text {st }}$ International Symposium on Society and Resource Management, June 13-18, 2015, Charleston, South Carolina, USA.

BRIDGE, G., BOUZAROVSKI, S., BRADSHAW, M., EYRE, N. (2013): Geographies of energy transition: Space, place and the low-carbon economy. Energy Policy, 53: 331-340.

BROTHERTON, B., HIMMETOĞLU, B. (1997). Beyond destinations - special interest tourism. Anatolia, 8(3): 11-30.
CETKOVSKÝ, S., NOVÁKOVÁ, E. (2009): Assessment of the impact of wind turbines on landscape character: Implications for landscape planning. Moravian Geographical Reports, 17(2): 28-34.

DANIEL, T. C., MEITNER, M. M. (2001): Representational Validity of Landscape Visualizations: The Effects of Graphical Realism on Perceived Scenic Beauty of Forest Vistas. Journal of Environmental Psychology, 21(1): 61-72.

DE SOUSA, A. J. G., KASTENHOLZ, E. (2015): Wind farms and the rural tourism experience-problem or possible productive integration? The views of visitors and residents of a Portuguese village. Journal of Sustainable Tourism, 23(8-9): 1236-1256.

DEVINE-WRIGHT, P. (2011): From backyards to places: public engagement and the emplacement of renewable energy technologies. In: Devine-Wright, P. [ed.]: Renewable energy and the public. From NIMBY to participation (pp. 57-74), London, Earthscan.

DEVINE-WRIGHT, P., HOWES, Y. (2010): Disruption of place attachment and the protection of restorative environments: A wind energy case study. Journal of Environmental Psychology, 30(3): 271-280.

EDWARDS, J.A., LLURDÉS, J. C. (1996): Mines and quarries: Industrial heritage tourism. Annals of Tourism Research, 23(2): 341-363.

ECHELBERGER, H. E. (1979): The semantic differential in landscape research. In: Elsner, G. H., Smardon, R. C. [eds.]: Proceedings of our national landscape: a conference on applied techniques for analysis and management of the visual resource (pp. 524-531). [Incline Village, Nev., April 23-25, 1979]. Forest Service, U.S. Department of Agriculture, Berkeley, CA.

FRANTÁL, B., KUNC, J. (2011): Wind turbines in tourism landscapes. Annals of Tourism Research, 38(2): 499-519.

FRANTÁL, B., URBÁNKOVÁ, R. (2017): Energy tourism: An emerging field of study. Current Issues in Tourism, 20 (13): 1395-1412.

GEE, K. (2010): Offshore wind power development as affected by seascape values on the German North Sea coast. Land Use Policy, 27(2): 185-194.

GUNNARSSON, B., GUNNARSSON, M. V. (2002). Iceland's Central Highlands: nature conservation, ecotourism, and energy resource utilization. In: Watson, A. E., Alessa, L., Sproull, J. [eds.]: Wilderness in the circumpolar north: searching for compatibility in ecological, traditional, and ecotourism values. Conference proceedings. Anchorage, 15-16 May 2001 (pp. 54-63). Rocky Mountain Research Station, USDA Forest Service.

GYLFASON， T.， WIJKMAN， P. M. (2015): Double diversification with an application to Iceland. CESifo Working Paper Series No. 5386: 2-33.

HARVEY, D. (1994): Justice, nature and the geography of difference. Oxford, Blackwell Publishing.

HIDALGO, M. C., HERNANDEZ, B. (2001): Place attachment: conceptual and empirical questions. Journal of Environmental Psychology, 21(3): 273-281.

JALLOULI, J., MOREAU, G. (2009): An immersive pathbased study of wind turbines' landscape: A French case in Plouguin. Renewable Energy, 34(3): 597-607. 
KAPLAN, R. (1985). The analysis of perception via preference: a strategy for studying how the environment is experienced. Landscape Planning, 12(2): 161-176.

KARLSDÓTTIR, U. B. (2013): Iceland and the North: an idea of belonging and being apart. In: Jørgensen, D., Sörlin, S. [eds.]: Northscapes: History, Technology and the Making of Northern Environments. Vancouver, UBC Press.

KAYMAZ, I. C. (2012). Landscape perception. In: Ozyavuz, M. [ed.]: Landscape planning. Intech [online]. Available at: http://www.intechopen.com/books/landscape-planning/ landscapeperception

KIM, N. H., KANG, H. H. (2009): The aesthetic evaluation of coastal landscape. KSCE Journal of Civil Engineering, 13(2): 65-74.

KONTOGIANNI, A., TOURKOLIAS, C., SKOURTOS, M., DAMIGOS, D. (2014): Planning globally, protesting locally: Patterns in community perceptions towards the installation of wind farms. Renewable Energy, 66: 170-177.

LANDSVIRKJUN (2017): Búrfell Wind Farm EIA report [online]. Available at: http://burfellwindfarm. landsvirkjun.com/

LIN, C.-C., LOCKWOOD, M. (2014): Forms and sources of place attachment: evidence from two protected areas. Geoforum, 53: 74-81.

LLEWELLYN, D. H., ROHSE, M., DAY, R., FYFE, H. (2017): Evolving energy landscapes in the South Wales Valleys: Exploring community perception and participation. Energy Policy, 108: 818-828.

LOTHIAN, A. (2008): Scenic perceptions of the visual effects of wind farms on South Australian landscapes. Geographical Research, 46(2): 196-207.

LYNCH, K. (1960): The image of the city. Cambridge, MIT Press.

MAEHR, A. M., WATTS, G. R., HANRATTY, J., TALMI, D. (2015): Emotional response to images of wind turbines: A psychophysiological study of their visual impact on the landscape. Landscape and Urban Planning, 142: 71-79.

MASSEY, D. (2004): Geographies of responsibilities. Geografiska Annaler, Series B, Human Geography, 86(1): 5-18.

MINISTRY FOR THE ENVIRONMENT AND NATURAL RESOURCES (1999): The Nature Conservation Act no. 44/1999. Article 3: Definitions.

MOLNÁROVÁ, K., SKLENIČKA, P., STIBOREK, J., SVOBODOVÁ, K., ŠÁLEK, M., BRABEC, E. (2012): Visual preferences for wind turbines: Location, numbers and respondent characteristics. Applied Energy, 92: 269-278.

NATORI, Y., CHENOWETH, R. (2008): Differences in rural landscape perceptions and preferences between farmers and naturalists. Journal of Environmental Psychology, 28(3): 250-267.

NOVÁKOVÁ, E., FRANTÁL, B. (2009): Application of visualisation methods in spatial planning: a case of wind power installations. Geodetický a kartografický obzor, 55/97(5): 111-113.

ÓLAFSDÓTTIR, R., RUNNSTRÖM, M. C. (2011): How wild is Iceland? Wilderness quality with respect to naturebased tourism. Tourism Geographies, 13(2): 280-298.
ÓLAFSDÓTTIR, R., GUĐJÓNSDÓTTIR, G. L., SÆPÓRSDÓTTIR, A. D., STEFÁNSSON, P. (2015): Áhrif vindmyllaí Búrfellslundi á ferđa pjónustu og íbúa [online]. Available at: http://gogn.lv.is/files/2015/2015-072.pdf

ORKUSTOFNUN [National Energy Authority] (2016): Energy Statistics in Iceland 2015 [online]. Available at: http://os.is/gogn/os-onnur-rit/Orkutolur_2015-enskautfaersla2.pdf

ORKUSTOFNUN [National Energy Authority] (2017): Orkustofnun Data Repository OS-2017-T015-01 [online]. Available at: http://os.is/gogn/Talnaefni/OS2017-T015-01.pdf

OSGOOD, C. E., SUCI, G., TANNENBAUM, P. (1957): The measurement of meaning. Urbana, IL: University of Illinois Press.

PALMER, J. F., VANDERHEYDEN, V., ALVES, G., SISMANI, G. (2017): Best Focal Length to Represent a Landscape View Using a Single-Frame Photograph. Journal of Digital Landscape Architecture, (22017): 236-243.

PASQUALETTI, M. J. (2011): Social barriers to renewable energy landscapes. Geographical Review, 101(2): 201-223.

PEDERSEN, E., LARSMAN, P (2008): The impact of visual factors on noise annoyance among people living in the vicinity of wind turbines. Journal of Environmental Psychology, 28(4): 379-389.

RAGNARSSON, B. F., ODDSSON, G. V., UNNTHORSSON, R., HRAFNKELSSON, B. (2015): Levelized cost of energy analysis of a wind power generation system at Burfell in Iceland. Energies, 8(9): 9464-9485.

RAMMAÁzETLUN (2017): The Master Plan for Nature Protection and Energy Utilization. [online]. Available at: http://www.ramma.is/english

RAYMOND, C. M., BROWN, G., WEBER, D. (2010): The measurement of place attachment: personal, community, and environmental connections. Journal of Environmental Psychology 30 (4): 422-434.

RIBE, R. G., MANYOKY, M., WISSEN HAYEK, U., PIEREN, R., HEUTSCHI, K., GRĘT-REGAMEY, A. (2018): Dissecting perceptions of wind energy projects: A laboratory experiment using high-quality audio-visual simulations to analyze experiential versus acceptability ratings and information effects. Landscape and Urban Planning, 169: 131-147.

SKIPULAGSSTOFNUN [National Planning Agency] (2016): Landsskipulagsstefna 2016-2026 [National Planning Strategy 2016-2026] [online]. Available at: http://www.landsskipulag.is/media/pdf-skjol/ Landsskipulagsstefna_2015-2026_asamt_greinargerd.pdf

SÆPÓRSDÓTTIR, A. D. (2010): Tourism struggling as the Icelandic wilderness is developed. Scandinavian Journal of Hospitality and Tourism, 10(3): 334-357.

SÆPÓRSDÓTTIR, A. D. (2012): Tourism and power plant development: An attempt to solve land use conflicts. Tourism Planning \& Development, 9(4): 339-353.

SÆPÓRSDÓTTIR, A. D., ÓLAFSSON, R. (2010a): Nature tourism assessment in the Icelandic Master Plan for geothermal and hydropower development. Part I: rapid evaluation of nature tourism resources. Journal of Heritage Tourism, 5(4): 311-331. 
SÆPÓRSDÓTTIR, A. D., ÓLAFSSON, R. (2010b): Nature tourism assessment in the Icelandic Master Plan for geothermal and hydropower development. Part II: assessing the impact of proposed power plants on tourism and recreation. Journal of Heritage Tourism, 5(4): 333-349.

SÆPÓRSDÓTTIR, A. D., SAARINEN, J. (2016): Changing ideas about natural resources: tourists' perspectives on the wilderness and power production in Iceland. Scandinavian Journal of Hospitality and Tourism, 16(4): 404-421.

SCOTT, A., CARTER, C., BROWN, K., WHITE, V. (2009). 'Seeing is Not Everything': Exploring the Landscape Experiences of Different Publics. Landscape Research, 34(4): 397-424.

SIBILLE， A. D. C. T., CLOQUELL-BALLESTER, V. A., CLOQUELL-BALLESTER, V. A., DARTON, R. (2009): Development and validation of a multicriteria indicator for the assessment of objective aesthetic impact of wind farms. Renewable and Sustainable Energy Reviews, 13(1): 40-66.

STEFÁNSSON, P., SÆPÓRSDÓTTIR, A. D., HALL, C. M. (2017): When tourists meet transmission lines: The effects of electric transmission lines on tourism in Iceland. Energy Research \& Social Science, 34: 82-92.

SVOBODOVÁ, K., SKLENIČKA, P., MOLNÁROVÁ, K. VOJAR, J. (2014): Does the composition of landscape photographs affect visual preferences? The rule of the Golden Section and the position of the horizon. Journal of Environmental Psychology, 38: 143-152.

TRESS, B., TRESS, G. (2001): Capitalising on multiplicity: a transdisciplinary systems approach to landscape research. Landscape and urban planning, 57(3): 143-157.

UEDA, H., NAKAJIMA, T., TAKAYAMA, N., PETROVA, E., MATSUSHIMA, H., FURUYA, K., AOKI, Y. (2012): Landscape image sketches of forests in Japan and Russia. Forest Policy and Economics, 19: 20-30.

UUSITALO, M. (2010): Differences in tourists' and local residents' perceptions of tourism landscapes: A case study from Ylläs, Finnish Lapland. Scandinavian Journal of Hospitality and Tourism, 10(3): 310-333.
VAN DER HORST, D. (2007): NIMBY or not? Exploring the relevance of location and the politics of voiced opinions in renewable energy siting controversies. Energy Policy, 35(5): 2705-2714.

VAN VEELEN, B., HAGGETT, C. (2016): Uncommon Ground: The role of different place attachments in explaining community renewable energy projects. Sociologia Ruralis (online first), DOI: 10.1111/soru.12128.

VECCHIATO, D. (2014): How do you like wind farms? Understanding people's preferences about new energy landscapes with choice experiments. Aestimum, 64: 15-37.

VOREL, I. (2009): Větrné elektrárny a charakter, ráz a identita kulturní krajiny. Paper presented at the Workshop Větrné elektrárny a životní prostředí, 10.3.2009, Jindřichův Hradec.

VORKINN, M., RIESE, H. (2001): Environmental Concern in a Local Context: The Significance of Place Attachment. Environment and Behavior, 33(2): 249-263.

WAAGE, E. R. H., JÓHANNESDÓTTIR, G. R. (2017): Whose values? Different perspectives and relations to energy landscapes. Paper presented at the $7^{\text {th }}$ Nordic Geographers Meeting, June 18-21, 2017, Stockholm, Sweden.

WALKER, G. (2011): The role for 'community' in carbon governance. Wiley Interdisciplinary Reviews: Climate Change, 2(5): 777-782.

WHYTE, A. (1977): Guidelines for field studies in environmental perception. (MAB Technical Notes 5). Paris, UNESCO.

WOLSINK, M. (2007): Planning of renewables schemes: Deliberative and fair decision-making on landscape issues instead of reproachful accusations of non-cooperation. Energy Policy, 35(5): 2692-2704.

ZUBE, E. H., PITT, D. G. (1981): Cross-cultural perceptions of scenic and heritage landscapes. Landscape planning, 8(1): 69-87.

\section{Please cite this article as:}

FRANTÁL, B., BEVK, T., VAN VEELEN, B., HĂRMĂNESCU, M., BENEDIKTSSON, K. (2017): The importance of on-site evaluation for placing renewable energy in the landscape: A case study of the Búrfell wind farm (Iceland). Moravian Geographical Reports, 25(4): 234-247. Doi: 10.1515/mgr-2017-0020. 